\title{
TUNNELING ATAU VALUE ADDED DALAM STRATEGI MERGER DAN AKUISISI DI INDONESIA
}

\author{
Mutamimah* \\ FE UNISSULA SEMARANG
}

\begin{abstract}
The purpose of this research is to analyze the effect of merger and acquisition strategy for majority and minority shareholders at Indonesia capital market. This research is important since most of company ownership structure in Indonesia is categorized concentrated structure, where its create a conflict between majority and minority shareholders. The population of the researh are companies that go public in the Indonesia capital market until the year of 2006. These samples of this research consists of 35 companies, divided two groups : high and low concentrated ownership structure, that are selected based on purposive sampling method. In processes testing the hypothesis, 2 indicators were used, i.e. market indicator and accounting indicator. Event study analysis was used for market indicator, whereas multiple regression analysis was used for accounting indicator. The results show a market reaction negative and statistically significant on merger and acquisition announcement. Effect of merger and acquisition strategy on performance is negative and statistically significant. This is indicated that tunneling by majority shareholder to minority shareholders through merger and acquisition strategy, and acquisition not value added for shareholder minority.
\end{abstract}

Keywords: tunneling, value added, merger and acquisition strategy, majority and minority shareholders

\section{PENDAHULUAN}

\section{Latar Belakang Penelitian}

Konflik keagenan merupakan konflik yang bersifat fenomenal dan terjadi karena adanya pemisahan antara kepemilikan dan kontrol dalam perusahaan, seperti dijelaskan oleh teori Keagenan (Jensen dan Meckling, 1976). Teori tersebut menyatakan, bahwa konflik keagenan terjadi jika pemilik perusahaan menyerahkan pengelolaannya kepada pihak lain, atau jika pemilik perusahaan bekerja sama dengan pihak lain.

Konflik keagenan tersebut terjadi antara pemegang saham dengan manajer atau antara pemegang saham dengan kreditur (Jensen dan Meckling, 1976). Namun dalam perkembangannya, konflik keagenan juga terjadi antara pemegang saham mayoritas dengan pemegang saham minoritas, antara pemegang saham 
mayoritas dengan stakeholder lain, seperti pemasok dan karyawan (Zhuang et al., 2000; dan Ariyoto, 2000).

Struktur kepemilikan di Indonesia terkonsentrasi pada sedikit pemilik (Claessens, Djankov, dan Lang, 2000; Zhuang et al., 2000; Gunarsih, 2003), sehingga konflik keagenan yang terjadi adalah konflik antara pemegang saham mayoritas dengan pemegang saham minoritas (Prowsen, 1998). Karakteristik lain dari struktur kepemilikan terkonsentrasi adalah apabila dalam perusahaan terdapat satu atau lebih pemegang saham terbesar sebagai pemegang saham pengendali yang mempunyai minimal 20\% saham (peraturan Bapepam no. IX.H.1).

Strategi merger dan akuisisi merupakan strategi bisnis yang banyak dipilih oleh perusahaan agar tetap unggul dalam persaingan. Motivasi perusahaan melakukan merger dan akuisisi adalah untuk melakukan sinergi dan meningkatkan nilai tambah (value added) bagi seluruh pemegang saham (Khanna dan Palepu, 1997 dan 2000). Strategi merger dan akuisisi di Indonesia didukung oleh pemerintah melalui Peraturan Bapepam no. IX.E.l yang melindungi hak-hak pemegang saham minoritas. Peraturan ini menjelaskan bahwa setiap transaksi yang mengandung benturan kepentingan harus mendapat persetujuan dari pemegang saham independen (minoritas), sehingga meskipun pemegang saham utama setuju dengan sebuah transaksi atau keputusan, namun apabila pemegang saham independen (minoritas) tidak setuju, maka transaksi tersebut tetap tidak boleh dilaksanakan. Melalui rapat umum pemegang saham (RUPS), tercermin bahwa kepentingan pemegang saham independen atau minoritas terlindungi dari perilaku moral hazard yang dilakukan oleh pemegang saham mayoritas, karena mereka mempunyai kekuatan untuk menolak suatu transaksi benturan kepentingan yang tidak mereka setujui, meskipun kepemilikan saham mereka amat kecil.

Namun di Korea yang mempunyai karakteristik bisnis yang sangat terkonsentrasi pada kelompok (Korean Business groups), justru strategi merger dan akuisisi sebagai sarana tunneling oleh pemegang saham mayoritas yang merugikan pemegang saham minoritas (Bae Kee Hong, et al., 2002). Tunneling merupakan pentransferan sumberdaya keluar perusahaan untuk keuntungan pemegang saham pengendali (Johnson et al., 2000). Holmen dan Knopf (2004) menunjukkan adanya tunneling di Swedia dari pemegang saham mayoritas dan tidak menemukan adanya peningkatan kesejahteraan yang cukup signifikan dari perusahaan pemerger ke perusahaan target.

Berdasarkan dari latar belakang tersebut, dalam penelitian ini, diuji 2 pandangan dari strategi merger dan akuisisi pada struktur kepemilikan terkonsentrasi, yaitu: 1). Pandangan Khanna dan Palepu $(1997,2000)$ yang menjelaskan bahwa strategi merger dan akuisisi memberikan manfaat bagi shareholdes, yang disebut dengan "value added view", 2). Pandangan Johnson et al. (2000) yang menjelaskan bahwa strategi merger dan akuisisi dengan mentransfer kemakmuran dan memberikan 
keuntungan bagi pemegang saham mayoritas dan merugikan pemegang saham minoritas, disebut "tunneling view".

\section{Rumusan Masalah Penelitian}

a. Bagaimana reaksi pasar terhadap pengumuman merger dan akuisisi pada strutur kepemilikan terkonsentrasi.

b. Bagaimana reaksi pasar terhadap pengumuman merger dan akuisisi, baik pada struktur kepemilikan terkonsentrasi tinggi maupun rendah.

c. Bagaimana pengaruh investasi terhadap kinerja struktur kepemilikan terkonsentrasi

d. Bagaimana pengaruh investasi terhadap kinerja struktur kepemilikan terkonsentrasi tinggi maupun rendah.

\section{Tujuan Penelitian}

a. Untuk menguji dan menganalisis reaksi pasar terhadap pengumuman merger dan akuisisi pada struktur kepemilikan terkonsentrasi.

b. Untuk menguji dan menganalisis reaksi pasar terhadap pengumuman merger dan akuisisi, baik pada struktur kepemilikan terkonsentrasi tinggi maupun rendah.

c. Untuk menguji dan menganalisisi pengaruh investasi terhadap kinerja struktur kepemilikan terkonsentrasi.

d. Untuk menguji dan menganalisisi pengaruh investasi terhadap kinerja struktur kepemilikan terkonsentrasi tinggi maupun rendah.

\section{Kontribusi Penelitian}

Penelitian ini mempunyai 3 kontribusi, yaitu kontribusi empiris, metodologis, dan kebijakan. Kontribusi empiris menguji efektifitas strategi merger dan akuisisi bagi pemegang saham (baik pemegang saham mayoritas maupun pemegang saham minoritas). Strategi merger dan akuisisi ini memberikan nilai tambah (value added) bagi seluruh pemegang saham, jika strategi tersebut direaksi positif oleh pasar atau dapat meningkatkan kinerja perusahaan. Hasil penelitian ini diharapkan dapat memperkaya literatur merger dan akuisisisi dalam kaitannya dengan hak-hak pemegang saham dan struktur kepemilikan di emerging market. Selain itu penelitian ini diharapkan menjadi dasar untuk penelitian berikutnya terkait dengan merger dan akuisisi dan struktur kepemilikan.

Kontribusi kedua adalah kontribusi metodologis. Selama ini belum ada penelitian yang menguji keefektifan strategi merger dan akuisisi dalam struktur kepemilikan terkonsentrasi dengan indikator pasar dan indikator akuntansi. Penelitian ini melakukan analisis lebih lanjut dengan analisis 4 kuadran, yang menghubungkan antara aliran kas dengan set kesempatan investasi, sehingga hasilnya lebih baik. 
Kontribusi ketiga adalah kontribusi kebijakan. Hasil penelitian ini diharapkan dapat memberikan informasi kepada Bapepam dan bursa efek tentang strategi merger dan akuisisi di pasar modal Indonesia, dalam kaitannya dengan hak-hak pemegang saham minoritas dan struktur kepemilikan di pasar modal Indonesia.

\section{Kerangka Teoritis dan Pengembangan Hipotesis}

\section{Pengertian Merger dan Akuisisi}

Merger berasal dari bahasa Latin "mergere" yang artinya (1). Bergabung bersama, menyatu, berkombinasi (2). Menyebabkan hilangnya identitas karena terserap atau tertelan sesuatu. Merger didefinisikan sebagai penggabungan dua perusahaan yang kemudian hanya ada satu perusahaan yang tetap hidup sebagai badan hukum, sementara yang lainnya menghentikan aktivitasnya atau bubar. Sementara akuisisi berasal dari bahasa Latin acquisitio dan bahasa Inggris acquisition, makna harfiah akuisisi adalah membeli atau mendapatkan sesuatu/obyek untuk ditambahkan pada sesuatu/obyek yang telah dimiliki sebelumnya. Akuisisi dalam teminologi bisnis diartikan sebagai pengambilalihan kepemilikan atau pengendalian atas saham atau aset suatu perusahaan oleh perusaahaan lain, dan dalam peristiwa baik perusahaan pengambilalih atau yang diambil alih tetap eksis sebagai badan hukum yang terpisah (Moin, 2003). Namun untuk kasus di Indonesia, kedua istilah tesebut saling menggantikan satu dengan yang lain, serta dipakai secara bersamaan, yaitu merger dan akuisisi.

\section{Motif Melakukan Merger dan Akuisisi}

Pada prinsipnya terdapat dua motif yang mendorong sebuah perusahaan melakukan merger dan akuisisi, yaitu motif ekonomi dan motif non-ekonomi. Motif ekonomi berkaitan dengan esensi tujuan perusahaan yaitu meningkatkan nilai perusahaan atau memaksimumkan kemakmuran pemegang saham. Di sisi lain, motif non ekonomi adalah motif yang bukan didasarkan pada esensi tujuan perusahaan tersebut, tetapi didasarkan pada keinginan subyektif atau ambisi pribadi pemilik atau manajemen perusahaan (Moin, 2003).

\section{1) Motif ekonomi}

Esensi tujuan perusahaan dalam perspektif manajemen keuangan adalah seberapa besar perusahaan mampu menciptakan nilai (value creation) bagi perusahaan dan bagi pemegang saham. Merger dan akuisisi memiliki motif ekonomi yang tujuan jangka panjangnya adalah untuk mencapai peningkatan nilai tersebut. Oleh karena itu seluruh aktivitas dan pengambilan keputusan harus diarahkan untuk mencapai tujuan ini. Motif strategis juga termasuk motif ekonomi ketika aktivitas merger dan akuisisi dilakukan untuk mencapai posisi strategis perusahaan agar memberikan keunggulan kompetitif bagi perusahaan. 
Biasanya perusahaan melakukan merger dan akuisisi untuk mendapatkan economies of scale.

2) Motif sinergi

Salah satu motivasi atau alasan utama perusahaan melakukan merger dan akuisisi adalah menciptakan sinergi. Sinergi merupakan nilai keseluruhan perusahaan setelah merger dan akuisisi yang lebih besar daripada penjumlahan nilai masing-masing perusahaan sebelum merger dan akuisisi. Sinergi dihasilkan melalui kombinasi aktivitas secara simultan dari kekuatan atau lebih elemenelemen perusahaan yang bergabung sedemikian rupa sehingga gabungan aktivitas tersebut menghasilkan efek yang lebih besar dibandingkan dengan penjumlahan aktivitas-aktivitas perusahaan jika mereka bekerja sendiri.

3) Motif diversifikasi

Diversifikasi adalah strategi pemberagaman bisnis yang bisa dilakukan melalui merger dan akuisisi. Diversifikasi dimaksud untuk mendukung aktivitas bisnis dan operasi perusahaan untuk mengamankan posisi persaingan.

4) Motif non-ekonomi

Aktivitas merger dan akuisisi terkadang dilakukan bukan untuk kepentingan ekonomi saja tetapi juga untuk kepentingan yang bersifat non-ekonomi, seperti prestise dan ambisi. Motif non-ekonomi bisa berasal dari manajemen perusahaan atau pemilik perusahaan (hubrys hypothesis, ambisi pemilik).

\section{Struktur Kepemilikan Terkonsentrasi}

Struktur kepemilikan mencerminkan jenis konflik keagenan yang terjadi. Ada 2 macam struktur kepemilikan, yaitu struktur kepemilikan tersebar dan struktur kepemilikan terkonsentrasi. Pada struktur kepemilikan terkonsentrasi, seperti Jepang, Eropa, dan sebagainya, pemegang saham mayoritas dapat melakukan monitoring dan kontrol terhadap manajemen perusahaan, sehingga berpengaruh positif terhadap kinerja perusahaan (Shleifer dan Vishny, 1997; Zhuang et al., 2000; Wiwattanakantang, 2001). Namun, di negara-negara berkembang seperti Indonesia dan negara Asia lainnya, struktur kepemilikan terkonsentrasi yang secara umum didominasi oleh keluarga pendiri serta adanya perlindungan terhadap pemegang saham minoritas yang lemah menimbulkan konflik keagenan antara pemegang saham mayoritas dengan pemegang saham minoritas. Kondisi ini sesuai dengan pernyataan Prowsen (1998), bahwa konflik keagenan yang utama di Indonesia adalah konflik keagenan antara pemegang saham mayoritas dengan pemegang saham minoritas. 
Munculnya masalah keagenan antara pemegang saham mayoritas dengan pemegang saham minoritas ini disebabkan oleh beberapa hal berikut. Pertama, pemegang saham mayoritas terlibat dalam manajemen sebagai direksi atau komisaris yang kemungkinan besar melakukan ekspropriasi terhadap pemegang saham minoritas (Mitton, 2002). Kedua, hak suara yang dimiliki pemegang saham mayoritas melebihi hak atas aliran kasnya, karena adanya kepemilikan saham dalam bentuk bersilang, piramida, dan berkelas (Claessens, Djankov, dan Lang 2000). Dengan bentuk kepemilikan seperti ini mendorong pemegang saham mayoritas untuk mengutamakan kepentingan mereka sendiri yang sangat berbeda dengan kepentingan investor dan stakeholder lain. Ketiga, pemegang saham mayoritas mempunyai kekuatan untuk mempengaruhi manajemen dalam membuat keputusan-keputusan yang hanya memaksimumkan kepentingannya dan merugikan kepentingan pemegang saham minoritas. Keempat, adanya perlindungan hak-hak pemegang saham minoritas yang lemah, mendorong pemegang saham mayoritas untuk melakukan tunneling yang merugikan pemegang saham minoritas (Claessens dan Fan, 2002). Tunneling merupakan perilaku manajemen atau pemegang saham mayoritas yang mentransfer aset dan profit perusahaan untuk kepentingan mereka sendiri, namun biaya dibebankan kepada pemegang saham minoritas (Zhang, 2004). Contoh tunneling adalah tidak membagikan dividen, menjual aset atau sekuritas dari perusahaan yang mereka kontrol ke perusahaan lain yang mereka miliki dengan harga di bawah harga pasar, dan memilih anggota keluargannya yang tidak memenuhi kualifikasi untuk menduduki posisi penting di perusahaan (LaPorta et al., 2000).

\section{Pengembangan Hipotesis}

\section{Reaksi Pasar terhadap Pengumuman Merger dan Akuisisi Pada Struktur Kepemilikan Terkonsentrasi}

Pada struktur kepemilikan terkonsentrasi, terjadi konflik keagenan antara pemegang saham mayoritas dengan minoritas (Shleifer dan Vishny, 1997; Zhuang et al., 2000). Pemegang saham mayoritas mempunyai kekuatan untuk mempengaruhi manajer dalam pengambilan keputusan, sehingga keputusan yang dibuat hanya akan menguntungkan mereka dan merugikan pemegang saham minoritas.

Merger dan akuisisi merupakan strategi bisnis yang banyak dipilih oleh perusahaan agar tetap unggul dalam persaingan. Merger dan akuisisi di Indonesia didukung oleh pemerintah melalui Peraturan Bapepam no. IX.E.1 yang melindungi hak-hak pemegang saham minoritas. Peraturan ini menjelaskan bahwa setiap transaksi yang mengandung benturan kepentingan harus mendapat persetujuan dari pemegang saham independen (minoritas), sehingga meskipun pemegang saham utama setuju dengan sebuah transaksi atau keputusan, namun apabila pemegang saham independen (minoritas) tidak setuju, maka transaksi tersebut tetap tidak boleh dilaksanakan. Melalui rapat umum pemegang saham, kepentingan pemegang 
saham independen atau minoritas terlindungi dari perilaku moral hazard yang dilakukan oleh pemegang saham mayoritas, karena mereka mempunyai kekuatan untuk menolak suatu transaksi benturan kepentingan yang tidak mereka setujui meskipun kepemilikan saham mereka amat kecil. Fenomena inilah yang menunjukkan bahwa melalui merger dan akuisisi, pemegang saham minoritas terlindungi dari tindakan moral hazard yang dilakukan oleh pemegang saham mayoritas.

Merger dan akuisisi dimaksudkan untuk meningkatkan nilai tambah (value added) bagi pemegang saham. Tersedianya aliran kas bebas menunjukkan adanya sumber dana berlebihan (slack resources) dalam perusahaan yang dapat digunakan untuk pendanaan modal baru atau investasi (Gedajlovic, Yoshikawa, dan Hashimoto, 2001). Hasil investasi ini akan dinikmati oleh seluruh pihak yang terkait dengan perusahaan. McConnel dan Muscarella (1985), Chan, et al. (1990), dan Titman, Wei, dan Xie (2001) menemukan pengumuman merger dan akuisisi mempunyai pengaruh positif terhadap harga saham perusahaan.

\section{H1 : Pasar bereaksi positif terhadap pengumuman merger dan akuisisi pada struktur kepemilikan terkonsentrasi}

\section{Reaksi Pasar terhadap Pengumuman Merger dan Akuisisi pada Struktur Kepemilikan Terkonsentrasi Tinggi dan Rendah}

Struktur kepemilikan di Indonesia terkonsentrasi pada sedikit pemilik (Claessens, Djankov, dan Lang, 2000; Zhuang et al., 2000; Gunarsih, 2003). Claessens, Djankov, dan Lang (2000) menyatakan bahwa, 66,9\% dari 178 sampel perusahaan publik di Indonesia mempunyai struktur kepemilikan terkonsentrasi melalui bentuk piramida dengan keluarga sebagai pengendali utama. Zhuang et al., (2000) menunjukkan bahwa struktur kepemilikan di Indonesia adalah terkonsentrasi pada lima pemilik terbesar, yaitu sekitar 67,5\%. Hasil tersebut didukung oleh Gunarsih (2003), yang menyatakan bahwa, rata-rata $65 \%$ kepemilikan terkonsentrasi ada pada tiga pemilik besar dan dimiliki oleh institusi. Struktur kepemilikan di Indonesia tergolong struktur kepemilikan terkonsentrasi menentukan jenis konflik keagenan yang terjadi dalam perusahaan.

Pada struktur kepemilikan terkonsentrasi, konflik keagenan yang terjadi adalah konflik antara pemegang saham mayoritas dengan pemegang saham minoritas (Shleifer dan Vishny, 1997; Zhuang, et al., 2000). Hal ini sesuai dengan pernyataan Shleifer dan Vishny (1997), bahwa apabila kepemilikan terkonsentrasi sudah melewati batas tertentu, pemegang saham mayoritas dapat mengendalikan perusahaan secara penuh dan mereka cenderung membuat kebijakan yang dapat memberi manfaat kepada dirinya saja. 
Konflik keagenan yang terjadi sangat dipengaruhi oleh tingginya konsentrasi kepemilikan perusahaan. Pada struktur kepemilikan terkonsentrasi tinggi, konflik keagenan lebih tinggi dibanding pada struktur kepemilikan terkonsentrasi rendah (Gugler dan Yurtoglu, 2000; Dewenter dan Warther, 1998). Oleh karena itu, pengumuman merger dan akuisisi pada struktur kepemilikan terkonsentrasi tinggi direaksi positif lebih besar dibanding pada struktur kepemilikan terkonsentrasi rendah.

\section{H2 : Pasar bereaksi positif lebih besar terhadap pengumuman merger dan akuisisi pada struktur kepemilikan terkonsentrasi tinggi dibanding rendah}

\section{Pengaruh Investasi terhadap Kinerja Perusahaan pada Struktur Kepemilikan Terkonsentrasi}

Struktur kepemilikan menentukan jenis konflik yang terjadi. Struktur kepemilikan di Indonesia adalah struktur kepemilikan terkonsentrasi (Gunarsih, 2003). Konflik keagenan yang terjadi adalah konflik antara pemegang saham mayoritas dengan minoritas terjadi (Zhuang et al., 2000). Pemegang saham mayoritas mempunyai kekuatan untuk mengendalikan manajer dalam pengambilan keputusan, sehingga keputusan yang dibuat hanya akan menguntungkan mereka dan merugikan pemegang saham minoritas.

Kebijakan investasi dapat meningkatkan value bagi pemegang saham. Tersedianya aliran kas bebas menunjukkan adanya sumber dana berlebihan (slack resources) dalam perusahaan yang dapat digunakan untuk pendanaan modal baru atau investasi (Gedajlovic, Yoshikawa, dan Hashimoto, 2001). Hasil investasi ini akan dinikmati oleh seluruh pihak yang terkait dengan perusahaan. McConnel dan Muscarella (1985), Chan, et al. (1990), dan Titman, Wei, dan Xie (2001) menemukan pengumuman peningkatan investasi mempunyai pengaruh positif terhadap harga saham perusahaan. Oleh karena itu, untuk melindungi hak-hak pemegang saham minoritas dari tindakan tunneling yang dilakukan pemegang saham mayoritas, maka Bapepam mengeluarkan peraturan no IX.E.I dan no. IX.G.1 mengenai investasi atau merger dan akuisisi. Dengan kata lain, kebijakan investasi sebagai cerminan terlindunginya hak-hak pemegang saham minoritas dari tindakan tunneling yang dilakukan oleh pemegang saham mayoritas.

Sebagaimana disebutkan di atas bahwa, persetujuan dari pemegang saham minoritas sangat dibutuhkan, walaupun jumlah kepemilikan saham mereka kecil. Oleh karena itu, investasi mempunyai pengaruh positif terhadap kinerja perusahaan pada struktur kepemilikan terkonsentrasi. 
H3 : Investasi mempunyai pengaruh positif terhadap kinerja struktur kepemilikan terkonsentrasi

\section{Pengaruh Investasi terhadap Kinerja Perusahaan pada Struktur Kepemilikan Terkonsentrasi Tinggi dan Rendah}

Pada struktur kepemilikan terkonsentrasi, konflik keagenan yang terjadi adalah konflik antara pemegang saham mayoritas dengan minoritas (Shleifer dan Vishny, 1997; Zhuang et al.,2000). Kebijakan investasi dapat meningkatkan kinerja perusahaan, karena kelebihan kas yang ada digunakan untuk investasi. McConnel dan Muscarella (1985), Chan, et al. (1990), dan Titman, Wei, dan Xie (2001) menemukan pengumuman investasi mempunyai pengaruh positif terhadap harga saham perusahaan. Oleh karena itu, untuk melindungi hak-hak pemegang saham minoritas dari tindakan tunneling yang dilakukan pemegang saham mayoritas, maka Bapepam mengeluarkan peraturan no IX.E.1 dan no. IX.G.I mengenai investasi atau merger dan akuisisi. Kebijakan investasi sebagai cerminan terlindunginya hak-hak pemegang saham minoritas dari tunneling yang dilakukan oleh pemegang saham mayoritas.

Pengaruh investasi terhadap kinerja perusahaan tergantung pada tingkat struktur kepemilikan terkonsentrasi (Gugler dan Yurtoglu, 2000; Dewenter dan Warther, 1998). Investasi pada struktur kepemilikan terkonsentrasi tinggi mempunyai pengaruh positif lebih besar dibanding pada struktur kepemilikan terkonsentrasi rendah terhadap kinerja perusahaan.

\section{H4 : Investasi pada struktur kepemilikan terkonsentrasi tinggi mempunyai pengaruh positif lebih besar dibanding pada struktur kepemilikan terkonsentrasi rendah terhadap profitabilitas perusahaan}

\section{Metode Penelitian}

\section{Populasi dan Sampel}

Populasi dalam penelitian ini adalah seluruh perusahaan yang terdaftar di pasar modal Indonesia sampai tahun 2006. Sampel diperoleh sebanyak 35 perusahaan yang diperoleh melalui teknik nonprobabilitas dengan metode purposive sampling dengan kriteria-kriteria sebagai berikut. Pertama, perusahaan yang sahamnya dimiliki oleh pemegang saham dengan kepemilikan saham minimal $20 \%$. Hal ini sesuai dengan UU PM yang mendefinisi pemegang saham mayoritas adalah pemegang saham yang mempunyai minimal $20 \%$ saham. Kedua, perusahaan mengumumkan merger dan akuisisi. 
Sampel terbagi dalam 2 kelompok yaitu, 1) struktur kepemilikan terkonsentrasi rendah (SKT rendah), jika perusahaan dimiliki oleh individu atau institusi (sebagai largest shareholder) antara $20 \%$ sampai kurang dari $50 \%$ (ownership < 50\%); 2) struktur kepemilikan terkonsentrasi tinggi (SKT tinggi), jika perusahaan dimiliki oleh individu atau institusi (sebagai largest shareholder) sebesar $50 \%$ atau lebih (ownership $>=50 \%$ ). Kriteria struktur kepemilikan terkonsentrasi didasarkan pada UU PM no. IX.H.1, yang menjelaskan pemegang saham pengendali (controlling shareholder) adalah pihak yang memiliki saham atau efek yang bersifat ekuitas sebesar $20 \%$ atau lebih. Sampel berjumlah 35, terdiri dari: a) merger dan akuisisi SKT tinggi 20 sampel dan SKT rendah 15 sampel.

\section{Variabel dan Pengukurannya}

\section{Variabel Dependen}

Variabel dependen dalam penelitian ini adalah reaksi pasar dan profitabilitas perusahaan. Untuk menguji apakah strategi merger dan akuisisi dapat menambah nilai (value added) atau tunneling bagi pemegang saham ditunjukkan dengan indikator pasar dan indikator akuntansi. Indikator pasar menggunakan reaksi pasar, sedangkan indikator akuntansi menggunakan profitabilitas perusahaan.

Reaksi pasar yang diukur dengan average abnormal return (Husnan, 2001; Gugler dan Yurtoglu, 2000) dan cumulative average abnormal return (Gugler dan Yurtoglu, 2000). Average abnormal return yang diamati adalah saat pengumuman event $(t=$ $0)$. Cumulative average abnormal return yang diuji adalah 2 hari sebelum pengumuman sampai 2 hari setelah pengumumuman $(t=-2$ sampai $t=+2$ ) dan saat sampai 5 hari setelah pengumuman ( $t=0$ sampai $\dagger=+5$ ).

\section{Variabel Independen}

Variabel independen dalam penelitian ini adalah investasi. Untuk indikator pasar, investasi diproksikan dengan pengumuman merger dan akuisisi. Untuk indikator akuntansi, investasi diproksikan dengan rasio perubahan total assets, yaitu (total assets + - total assetst-1)/ (total assetst-1).

\section{Variabel Kontrol}

Ukuran perusahaan (size) digunakan sebagai variabel kontrol. Perusahaan besar cenderung mempunyai jumlah aset besar, terdiversifikasi dan nilai kapitalisasinya besar, sehingga berdampak positif terhadap profitabilitas perusahaan (Demsetz dan Lehn, 1985), Size = Ln Assets (Wiwattanakantang, 1999). 


\section{Jenis dan Sumber Data}

Jenis data yang digunakan dalam penelitian ini data sekunder, yaitu laporanlaporan keuangan perusahaan, tanggal pengumuman merger dan akuisisi, harga saham harian, indeks harga saham gabungan harian dan informasi-informasi lain yang terkait dengan penelitian ini. Tanggal pengumuman merger dan akuisisi adalah saat kebijakan tersebut diumumkan ke publik baik melalui media massa atau konferensi pers. Data diperoleh dari Indonesian Capital Market Directory, JSX Statistics, Pusat Riset Pasar Modal, Pusat Data Bisnis Indonesia, Harian Bisnis Indonesia, internet, database pasar modal PPA-UGM, dan sumber-sumber lain yang terkait dengan penelitian ini.

\section{Teknik Analisis}

\section{Indikator Pasar}

Untuk menjawab permasalahan penelitian, salah satu indikator yang digunakan adalah indikator pasar. Indikator pasat diukur dengan menghitung nilai average abnormal return dan cumulative average abnormal return. Event dalam penelitian ini adalah pengumuman merger dan akuisisi.

Abnormal return adalah selisih antara actual return dengan expected return. Cumulative abnormal return merupakan jumlah abnormal return selama periode window tertentu. Asumsi yang digunakan adalah tidak ada event lain selain pengumuman merger dan akuisisi selama periode pengamatan.

Adapun langkah-langkah pengujiannya sebagai berikut:

a. Menentukan estimation period, yaitu periode waktu yang digunakan untuk menforecast expected return saham. Periode estimasi yang digunakan dalam penelitian ini adalah 50 hari, yaitu $t_{-60}$ sampai $t_{-11}$. Periode ini dianggap cukup untuk mengestimasi koefisien parameter model regresi return pasar.

b. Menentukan event period, yaitu periode di sekitar event time (ketika event benar-benar terjadi). Event period yang dipilih dalam penelitian ini adalah 21 hari, yaitu $t=0,10$ hari sebelum pengumuman merger dan akuisisi dan 10 hari sesudah pengumuman merger dan akuisisi $\left(t_{-10}, t_{+10}\right)$.

c. Menghitung return pasar dengan rumus:

$R_{m t}=\left(I H S G_{t}-I H S G_{t-1}\right) / H S G_{t-1}$

$\mathrm{R}_{\mathrm{mt}}=$ return pasar

$\mathrm{IHSG}_{\dagger}=$ indeks harga saham gabungan pada periode $\dagger$

IHSG $_{\text {-1 }}=$ indeks harga saham gabungan pada periode t-1 
d. Menghitung actual return untuk saham i dengan rumus:

$\mathrm{R}_{\mathrm{it}}=\left(\mathrm{P}_{\mathrm{it}}-\mathrm{P}_{\mathrm{it}-1}\right) /\left(\mathrm{P}_{\mathrm{it}-1}\right)$

$\mathrm{R}_{\mathrm{it}}=$ return saham i pada periode

$\mathrm{P}_{\mathrm{it}}=$ harga saham $\mathrm{i}$ periode $\dagger$

$\mathrm{P}_{\mathrm{it}-\mathrm{l}}=$ harga saham $\mathrm{i}$ pada periode $\mathrm{t}-1$

e. Expected return dihitung dengan menggunakan model indeks tunggal, rumusnya:

$E\left(R_{i t}\right)=a_{i}+B_{i} R m_{i t}+e_{i t}$

$E\left(R_{i t}\right)=$ expected return untuk saham i periode $\dagger$

Oit = besarnya return saham individual yang tidak dipengaruhi harga pasar

$\beta_{\text {it }} \quad=$ tingkat kepekaan return saham individual sebagai akibat erubahan harga pasar

$\mathrm{Rm}_{\mathrm{it}} \quad=$ return pasar untuk periode $\dagger$

$e_{\text {it }} \quad=$ abnormal return

f. Abnormal return dari saham i dihitung dengan rumus:

$A R_{i t}=R_{i t}-\hat{a}_{i}-\hat{B} R m_{t}$

$\mathrm{AR}_{\mathrm{it}} \quad=$ abnormal return saham i pada periode $\dagger$

$\mathrm{R}_{\text {it }} \quad=$ actual return untuk saham i pada periode $\dagger$

$E\left(R_{m t}\right)=$ return pasar pada periode $\dagger$

$\mathrm{a}_{\mathrm{i}} \quad=$ besarnya return saham i yang tidak dipengaruhi oleh return pasar

$\beta_{\text {it }} \quad=$ kepekaan return saham i akibat berubahnya return pasar

g. Menghitung cumulative average abnormal return dengan rumus :

$\mathrm{CAAR}=\sum_{\mathrm{t}}^{\mathrm{k}} \mathrm{AAR}$

CAAR = cumulative average abnormal return

AAR = abnormal return

$\mathrm{k} \quad=$ jumlah hari perdagangan yang diamati 


\section{Indikator Akuntansi}

Diagnostic test dilakukan untuk menguji heteroskedastisitas. Uji heteroskedastitas dilakukan untuk mendeteksi apakah varian $\left(\sigma^{2}\right)$ dari variabel dependen naik sebagai akibat naiknya varian dari variabel independen. Untuk mendeteksi masalah heteroskedastisitas dilakukan uji Glejser (Gujarati, 2003). Uji Glejser dilakukan dengan meregres variabel-variabel independen (div, debt, invest, divown, debtown, dan investown) dengan variabel dependen (variabel residual yang telah diabsolutkan).

\section{Hasil Pengujian dan Pembahasan}

\section{Reaksi Pasar terhadap Pengumuman Merger dan Akuisisi pada Struktur Kepemilikan Terkonsentrasi}

Hipotesis la Menyatakan pasar bereaksi positif dan signifikan terhadap pengumuman merger dan akuisisi pada struktur kepemilikan terkonsentrasi. Hipotesis la didukung, apabila nilai average abnormal return (AAR $=0$ ) atau cumulative average abnormal return $\left(\mathrm{CAAR}_{2}=-2 ;+2\right)$ atau cumulative average abnormal return $\left(\mathrm{CAAR}_{5}=0 ;+5\right)$ pada pengumuman merger dan akuisisi adalah positif dan signifikan.

Tabel 1 menunjukkan average abnormal return pada saat pengumuman merger dan akuisisi $(A A R=0)$ negatif dan signifikan. Nilai cumulative average abnormal return $\left(\mathrm{CAAR}_{2}=-2 ;+2\right)$ dan cumulative average abnormal return $\left(\mathrm{CAAR}{ }_{5}=0 ;+5\right)$ adalah negatif, tetapi tidak signifikan. Dapat disimpulkan bahwa reaksi pasar terhadap pengumuman merger dan akuisisi pada hari $\dagger=0$ adalah negatif dan signifikan.

Setelah ditelusur lebih lanjut, reaksi negatif tersebut menunjukkan bahwa telah terjadi tunneling dalam strategi merger dan akuisisi pada struktur kepemilikan terkonsentrasi. Hal ini ditunjukkan oleh tabel 2 baris 2 dan kolom 3 terbukti nilai AAR dan CAAR5 negatif dan signifikan secara statistis.

Hasil tersebut menunjukkan bahwa pada kondisi aliran kas tinggi dengan kesempatan investasi rendah $(Q<1)$, konflik keagenan tinggi dan terbukti pengumuman merger dan akuisisi direaksi negatif dan signifikan oleh pasar. Hasil tersebut mengindikasikan bahwa strategi merger dan akuisisi tidak memberikan nilai tambah (value added) bagi pemegang saham, tetapi strategi merger dan akuisisi justru sebagai sarana tunneling bagi pemegang saham mayoritas yang merugikan pemegang saham minoritas. Hasil penelitian ini mendukung Marco dan Mengoli (1999); Bae, Kang, dan Kim (2002). 
Hasil tersebut memperkuat pernyataan Gugler (2001), bahwa secara umum agen lebih suka untuk menginvestasikan aliran kas bebas walaupun nilai investasinya negatif dibanding membagikan kas tersebut kepada pemegang saham. Hal ini karena besarnya ekspansi yang dilakukan oleh manajer akan mempengaruhi tingginya kompensasi yang mereka terima dan juga akan dapat meningkatkan prestise bagi manajer. Hasil ini tidak mendukung hipotesis 1.

\section{Reaksi Pasar terhadap Pengumuman Merger dan Akuisisi pada Struktur Kepemilikan Terkonsentrasi Tinggi dan Rendah}

Hipotesis 2 menyatakan bahwa pasar bereaksi positif terhadap pengumuman merger dan akuisisi pada struktur kepemilikan terkonsentrasi tinggi dengan lebih besar dibanding pada struktur kepemilikan terkonsentrasi rendah. Hipotesis 2 didukung, apabila nilai average abnormal return (AAR) atau cumulative abnormal return $\left(\mathrm{CAAR}_{2}, \mathrm{CAAR}_{5}\right)$ positif lebih besar pada struktur kepemilikan terkonsentrasi tinggi dibanding pada struktur kepemilikan terkonsentrasi rendah.

Tabel 2 menunjukkan nilai $A A R, C_{A A R}$ pada struktur kepemilikan terkonsentrasi tinggi negatif dan signifikan secara statistis. Nilai CAAR5 negatif tetapi tidak signifikan. Reaksi pasar saat pengumuman merger dan akuisisi pada struktur kepemilikan terkonsentrasi tinggi negatif dan signifikan.

Setelah ditelusur lebih lanjut, reaksi negatif tersebut menunjukkan telah terjadi tunneling melalui merger dan akuisisi pada struktur kepemilikan terkonsentrasi tinggi. Hal ini ditunjukkan oleh tabel 3 baris 2 dan kolom 3, nilai AAR dan CAAR5 negatif dan signifikan secara statistis. Pada kondisi aliran kas tinggi dengan kesempatan investasi rendah di mana konflik keagenan tinggi dan pengumuman merger dan akuisisi pada struktur kepemilikan terkonsentrasi tinggi direaksi negatif oleh pasar. Hasil ini mengindikasikan bahwa strategi merger dan akuisisi pada struktur kepemilikan terkonsentrasi tinggi digunakan sebagai sarana tunneling oleh pemegang saham mayoritas dan merugikan pemegang saham minoritas.

Pada tabel 3 menunjukkan nilai $A A R, C_{2 A R}, C_{2 A R}$ negatif dan signifikan secara statistis. Pada saat pengumuman merger dan akuisisi, pada 2 hari sebelum sampai 2 hari sesudah pengumuman akuisisi dan saat sampai 5 hari sesudah pengumuman akuisisi pada struktur kepemilikan terkonsentrasi rendah, reaksi pasar adalah negatif dan signifikan secara statistis.

Penelusuran reaksi pasar yang negatif pada struktur kepemilikan terkonsentrasi rendah (tabel 5). Pada tabel tersebut baris 2 dan kolom 3 menunjukkan nilai AAR dan CAAR5 negatif dan signifikan secara statistis.

Pada kondisi aliran kas tinggi dengan kesempatan investasi rendah, konflik keagenan tinggi, serta adanya pengumuman merger dan akuisisi pada struktur 
kepemilikan terkonsentrasi rendah direaksi negatif oleh pasar. Hal tersebut mengindikasikan bahwa strategi merger dan akuisisi pada struktur kepemilikan terkonsentrasi rendah digunakan sebagai sarana tunneling terhadap pemegang saham minoritas oleh pemegang saham mayoritas.

Reaksi negatif pada struktur kepemilikan terkonsentrasi tinggi lebih besar dibanding pada struktur kepemilikan terkonsentrasi rendah, dan perbedaannya signifikan secara statistis. Tunneling yang dilakukan oleh pemegang saham mayoritas terhadap pemegang saham minoritas melalui merger dan akuisisi lebih besar terjadi pada struktur kepemilikan terkonsentrasi tinggi dibanding pada struktur kepemilikan terkonsentrasi rendah. Hasil ini menunjukkan kekuatan pemegang saham mayoritas untuk melakukan tunneling lebih besar terjadi pada struktur kepemilikan terkonsentrasi tinggi dibanding pada struktur kepemilikan terkonsentrasi rendah. Hasil ini tidak mendukung hipotesis 2.

Tunneling melalui akuisisi pada struktur kepemilikan terkonsentrasi di atas disebabkan oleh beberapa hal. Pertama, pada struktur kepemilikan terkonsentrasi, pemegang saham mayoritas mempunyai insentif dan kemampuan untuk melakukan transaksi harga yang tidak fair untuk mengekspropriasi sumber-sumber (resources) dari kelompok perusahaan induk disalurkan ke kelompok perusahaan di bawahnya, fenomena ini disebut tunneling (Johnson, LaPorta, Lopez-de-Silanes, dan Shleifer, 2000). Pemegang saham mayoritas dapat juga menggunakan sumbersumber internal secara rahasia untuk membantu anak perusahaan yang sedang mengalami kerugian atau masalah, tindakan ini disebut propping (Sarkar dan Sarkar, 2005). Kedua, perlindungan terhadap pemegang saham minoritas di Indonesia lemah (Laporta-Lopez-de-Silanes, Shleifer, dan Vishny, 2000), sehingga kemungkinan terjadinya ekspropriasi terhadap pemegang saham minoritas sangat tinggi. Ketiga, adanya informasi asimetri antara pemegang saham mayoritas dengan minoritas yang tinggi, mendorong tindakan ekspropriasi melalui akuisisi oleh pemegang saham mayoritas. Shleifer dan Vishny (1997) menyatakan bahwa apabila kepemilikan terkonsentrasi sudah melewati batas tertentu, pemegang saham mayoritas dapat mengendalikan perusahaan secara penuh dan mereka cenderung membuat kebijakan yang hanya memberi manfaat kepada dirinya saja, dan merugikan pemegang saham minoritas. Pemegang saham mayoritas mempunyai kekuatan untuk mempengaruhi manajemen dalam membuat keputusan-keputusan yang hanya memaksimumkan kepentingannya dan merugikan kepentingan pemegang saham minoritas. Keempat, adanya perlindungan hak-hak pemegang saham minoritas yang lemah, mendorong pemegang saham mayoritas untuk melakukan "tunneling" yang merugikan pemegang saham minoritas (Johnson, et al., 2000 dan Bae, et al., 2002). Johnson et al. (2000) mendefinisikan bahwa tunneling merupakan penstransferan sumber daya dan laba keluar perusahaan untuk keuntungan pemegang saham pengendali. 
Hasil penelitian juga menunjukkan, bahwa besarnya reaksi pasar terhadap pengumuman merger dan akuisisi dari struktur kepemilikan terkonsentrasi tinggi negatif lebih besar dari struktur kepemilikan terkonsentrasi rendah, dan signifikan secara statistis. Terbukti bahwa strategi merger dan akuisisi tidak meningkatkan value added, tetapi juga menimbulkan adanya tunneling. Tunneling melalui strategi merger dan akuisisi pada struktur kepemilikan terkonsentrasi tinggi lebih besar dari struktur kepemilikan terkonsentrasi rendah dan perbedaannya signifikan. Hasil ini mengindikasikan beberapa hal. Pertama, perbedaan pengelompokan struktur kepemilikan terkonsentrasi tinggi dan rendah menjadi hal penting bagi pasar. Kedua, kekuatan pemegang saham mayoritas untuk mempengaruhi manajemen dalam pengambilan keputusan akuisisi lebih besar terjadi pada struktur kepemilikan terkonsentrasi tinggi dibanding pada struktur kepemilikan terkonsentrasi rendah, sehingga ekspropriasi melalui akuisisi lebih besar terjadi pada struktur kepemilikan terkonsentrasi tinggi dibanding rendah.

\section{Hasil Pengujian Indikator Akuntansi}

Diagnostic test dalam penelitian ini dilakukan dengan menguji heteroskedastisitas. Hasil regresi setelah dihilangkan masalah heteroskidastisitasnya, menunjukkan nilai koefisien variabel investasi atau perubahan total assets pada struktur kepemilikan terkonsentrasi mempunyai pengaruh positif terhadap kinerja perusahaan. Hipotesis 3 didukung, apabila nilai koefisien $\beta_{4}$ positif dan signifikan secara statistis. Hasil regresi tabel 7 menunjukkan bahwa koefisien variabel investasi positif $(23,52200)$ dan signifikan secara statistis. Hasil regresi tersebut menunjukkan bahwa kebijakan investasi mempunyai pengaruh positif terhadap kinerja perusahaan. Hasil ini mendukung hipotesis 3.

Hipotesis 4 menyatakan, bahwa investasi pada struktur kepemilikan terkonsentrasi tinggi mempunyai pengaruh positif lebih besar dari pada struktur kepemilikan terkonsentrasi rendah terhadap kinerja perusahaan. Hipotesis 4 didukung apabila nilai koefisien $\left(\beta_{2}+\beta 3\right.$ ) negatif lebih besar dari koefisien $\left(\beta_{4}\right)$ dan signifikan secara statistis. Hasil regresi menunjukkan nilai koefisien variabel investasi pada struktur kepemilikan terkonsentrasi tinggi adalah negatif $(23,52200+-23,5900)$, sedangkan nilai koefisien variabel investasi dari struktur kepemilikan terkonsentrasi rendah adalah positif $(23,52200)$ dan signifikan secara statistis. Investasi pada struktur kepemilikan terkonsentrasi tinggi, justru sebagai sarana tunneling terhadap pemegang saham minoritas. Hasil ini tidak mendukung hipotesis 4. Uji sensitivitas dilakukan dengan memasukkan variabel kontrol, yaitu size dan menunjukkan bahwa setelah memasukkan variabel size ke dalam persamaan regresi, ternyata variabel size tidak signifikan secara statistis. Artinya hasil regresi dari pengaruh variabelvariabel independen terhadap variabel dependen di atas bukan karena variabel size tetapi karena variabel-variabel itu sendiri. 


\section{Simpulan}

Penelitian ini menguji strategi merger dan akuisisi terhadap kemakmuran pemegang saham pada struktur kepemilikan terkonsentrasi. Pengujian tersebut bertujuan menjawab permasalahan apakah strategi merger dan akuisisi meningkatkan nilai tambah (value added) bagi pemegang saham atau justru sebagai tunneling pemegang saham mayoritas terhadap pemegang saham minoritas. Penelitian ini penting, karena struktur kepemilikan perusahaan di Indonesia adalah terkonsentrasi, sehingga konflik keagenan yang terjadi adalah konflik antara pemegang saham mayoritas dengan pemegang saham minoritas.

Berdasarkan hasil pengujian baik menggunakan indikator pasar maupun indikator akuntansi, dapat disimpulkan bahwa strategi merger dan akuisisisi tidak memberikan nilai tambah (valve added) bagi pemegang saham mayoritas dan minoritas, baik pada struktur kepemilikan terkonsentrasi tinggi maupun rendah. Strategi merger dan akuisisi justru digunakan sebagai tunneling terhadap pemegang saham minoritas oleh pemegang saham mayoritas. Tunneling lebih besar terjadi pada pada struktur kepemilikan terkonsentrasi tinggi dibanding pada struktur kepemilikan terkonsentrasi rendah.

\section{Keterbatasan dan Saran}

Penelitian ini mempunyai keterbatasan-keterbatasan, antara lain. Pertama, penentuan $t=0$ secara tepat sangat sulit, sehingga ketika penentuan $t=0$ tidak tepat akan memperlemah hasil penelitian. Kedua, proksi struktur kepemilikan terkonsentrasi yang digunakan dalam penelitian ini adalah kepemilikan maksimum oleh individu atau institusi dengan kepemilikan minimal $20 \%$ saham, oleh karena itu penelitian berikutnya bisa menggunakan proksi konsentrasi kepemilikan yang berbeda, misalnya menggunakan herfindahl index, institusi, dan sebagainya. Ketiga, untuk mengetahui keefektifan strategi merger dan akuisisi tidak cukup dengan menggunakan data sekunder saja. Oleh karena itu penelitian yang akan datang akan lebih baik, jika dilengkapi dengan data-data primer sehingga diharapkan bisa diperoleh hasil penelitian yang lebih baik.

\section{Daftar Referensi}

Agrawal, Anup and CR. Knoeber (1996),"Firm Performance and Mechanism to Control Agency Problems between Managers and Shareholders", Journal of Financial and Quantitative Analysis, September, pp. 377-397.

Ariyoto, Kresnohadi (2000),"Good Corporate Governance dan Konsep Penegakannya di BUMN dan Lingkungan Usahanya", Majalah Usahawan, no. 10 th XXIX, Oktober, pp. 3- 17. 
Bae Kee H., Jun Koo Kang And Jin-Mo Kim (2002),"Tunneling Or Value Added? Evidence From Merger By Korean Business Groups, The Journal Of Finance, Vo. LVII.No.6 P.2695-2740.

Bigelli, Marco, and S. Mengoli (2000),"Sub Optimal Acquisition Decisions Under A Majority Shareholder System : An Empirical Investigation", working paper, http://SSRN.Com.

Claessens, Stijn, Simeon Djankov, Larry H.P. Lang, (2000),"The Separation of Ownership and Control in East Asian Corporations, Journal of Financial Economics, pp. 81-112.

Claessens, Stijn, Simeon Djankov, Larry H.P. Lang, (2002),"Expropriation of Minority Shareholders in East Asia", The Journal of Finance.

Gedajlovic Eric R., Toru Yoshikawa, dan Motomi Hashimoto (2001),"Ownership Structure, Investment Behavior and Firm Performance in Japanese Manufacturing Industries", walking paper, Erasmus Research Institute o Management.

Gugler and Yurtoglu (2000),"Corporate Governance and Dividend Pay-Out Policy in Germany", Europian Economic Review.

Gunarsih, Tri (2003),"Pengaruh Struktur Kepemilikan dalam Corporate Governance dan Strategi Diversifikasi Terhadap Kinerja Perusahaan", disertasi, tidak dipublikasikan, UGM, Yogyakarta.

Johnson Simon, Rafael La Porta, Florencio Lopez de Silanes and Andrei Shleifer (2000)," Tunneling", American Economic Review Review Papers and Proceeding 90,22-27.

Holmen, Martin and John D. Knopf (2004),"Minority Shareholder Protection and The Private Benefits of Control for Swedish Mergers", Journal of Financial and Quantitative Analysis, Vol.39. No. 1, p 167-191.

Khanna, Tarun and Krisna Palepu (1999),"Emerging Market Business Group, Foreign Investor, and Corporate Governance", National Bureau of Economic Research, Workingpaper,>http.//www.nber.org./papers.

Mitton (2002)," A Cross Firm Analysis of the Impact of Corporate Governance on The East Asian Financial Crisis", Journal of Financial Economics, pp. 1-31.

Moin, Abdul. (2003). Merger, Akvisisi dan Divestasi. Jilid 1. Yogyakarta: Ekonisia.

Riyanto, Bambang dan Gudono (1996),"An Assesment of The Impact of Compensation Plans on Stock Market Return : The Case of Merger and Acquisitions", Kelola no. 12., UGM, Yogyakarta.

Zhuang, Juzhong, David Edwards, David Webb, Ma. Virginita A. Capulong (2000),"Corporate Governance and Finance in East Asia - A Study of Indonesia, Republic of Korea, Malaysia, Philippines, and Thailand", Asian Development Bank, Manila. 


\section{LAMPIRAN}

\section{Tabel 1}

\section{AAR dan CAAR \\ Merger dan akuisisi}

AAR (Average Abnormal Return) menunjukkan besarnya reaksi pasar pada periode $\dagger$ atau saat pengumuman merger dan akuisisi. CAAR 2 (Cumulative Average Abnormal Return) menunjukkan reaksi pasar pada periode 2 hari sebelum sampai 2 hari sesudah pengumuman merger dan akuisisi. CAAR5 (Cumulative Average Abnormal Return) menunjukkan reaksi pasar pada saat sampai 5 hari setelah pengumuman merger dan akuisisi. * signifikan pada $\alpha=$ $5 \%$.

\begin{tabular}{cccc}
\hline Strategi & $\begin{array}{c}\text { AAR } \\
\text { (t-value) }\end{array}$ & $\begin{array}{c}\text { CAAR } \\
\text { (t-value) }\end{array}$ & $\begin{array}{c}\text { CAAR } \\
\text { (t-value) }\end{array}$ \\
\hline Merger dan & $-0,00597$ & $-0,00611$ & $-0,00446$ \\
Akuisisi & $(-9,53140)^{*}$ & $(-1,00019)$ & $(-0,10555)$ \\
\hline
\end{tabular}

Tabel 2

Hubungan Aliran Kas Bebas dengan Set Kesempatan Investasi Merger dan Akuisisi

AAR (Average Abnormal Return) menunjukkan besarnya reaksi pasar pada periode $t$ atau saat pengumuman merger dan akuisisi. CAAR 2 (Cumulative Average Abnormal Return) menunjukkan reaksi pasar pada periode 2 hari sebelum sampai 2 hari sesudah pengumuman merger dan akuisisi. CAAR5 (Cumulative Average Abnormal Return) menunjukkan reaksi pasar pada saat sampai 5 hari setelah pengumuman merger dan akuisisi. ${ }^{*}$ signifikan pada $\alpha=$ 5\%. IOS menunjukkan set kesempatan investasi. CF menunjukkan aliran kas.

\begin{tabular}{|c|c|c|}
\hline$\frac{\mathrm{IOS}}{\mathrm{CF}}$ & Tinggi & Rendah \\
\hline Tinggi & $\begin{aligned} \mathrm{AAR} & =-0,011383(-1,10540) \\
\mathrm{CAAR}_{2} & =-0,01840(-0,51436) \\
\mathrm{CAAR}_{5} & =-0.0526](-1,44080)\end{aligned}$ & $\begin{array}{l}\text { AAR }=-0,00416(-16,28470)^{*} \\
\text { CAAR }=-0,00359(-0,33653)\end{array}$ \\
\hline & $\mathrm{CAAR}_{5}=-0,05261(-1,44080)$ & CAAR $_{5}=-0,07108(-7,22820)^{*}$ \\
\hline Rendah & $\begin{array}{l}A A R=0,012975(0,502520) \\
C A A R_{2}=0,01883(0,91410)\end{array}$ & $\begin{array}{c}\text { AAR }=-0,00696(-0,59856) \\
\text { CAAR }_{2}=-0,02545(-1,26081)\end{array}$ \\
\hline & $\mathrm{CAAR}_{5}=0,05647(1,10430)$ & CAAR $=-0,04272(-0,84910)$ \\
\hline
\end{tabular}




\section{Tabel 3 \\ AAR dan CAAR \\ Merger dan Akuisisi pada SKT Tinggi dan Rendah}

AAR (Average Abnormal Return) menunjukkan besarnya reaksi pasar pada periode $\dagger$ atau saat pengumuman merger dan akuisisi. CAAR 2 (Cumulative Average Abnormal Return) menunjukkan reaksi pasar pada periode 2 hari sebelum sampai 2 hari sesudah pengumuman merger dan akuisisi. CAAR5 (Cumulative Average Abnormal Return) menunjukkan reaksi pasar pada saat sampai 5 hari setelah pengumuman merger dan akuisisi.*signifikan pada $\alpha=5 \%$, SKT tinggi menunjukkan struktur kepemilikan terkonsentrasi tinggi, SKT rendah menunjukkan struktur kepemilikan terkonsentrasi rendah.

\begin{tabular}{cccc}
\hline $\begin{array}{c}\text { Kelompok } \\
\text { Sampel }\end{array}$ & $\begin{array}{c}\text { AAR } \\
\text { (t-value) }\end{array}$ & $\begin{array}{c}\text { CAAR } \\
\text { (t-value) }\end{array}$ & $\begin{array}{c}\text { CAAR5 } \\
\text { (t-value) }\end{array}$ \\
\hline 1. SKT tinggi & $-0,02219$ & $-0,01014$ & 0,00814 \\
& $(-3,65000)^{*}$ & $(-2,98261)^{*}$ & $(0,23399)$ \\
\hline Uji beda & 0,01500 & $-0,01217$ & 0,00631 \\
(t value) & $(1,98230)^{*}$ & $(-2,13400)^{*}$ & $(0,12100)$ \\
\hline 2. SKT rendah & $-0,00974$ & $-0,00208$ & $-0,02476$ \\
& $(-2,05915)^{*}$ & $(-1,97104)^{*}$ & $(-2,36248)^{*}$ \\
\hline
\end{tabular}

\section{Tabel 4 \\ Hubungan Aliran Kas Bebas dengan Set Kesempatan Investasi Merger dan Akuisisi \\ SKT Tinggi}

AAR (Average Abnormal Return) menunjukkan besarnya reaksi pasar pada periode $t$ atau saat pengumuman merger dan akuisisi. CAAR 2 (Cumulative Average Abnormal Return) menunjukkan reaksi pasar pada periode 2 hari sebelum sampai 2 hari sesudah pengumuman merger dan akuisisi. CAAR 5 (Cumulative Average Abnormal Return) menunjukkan reaksi pasar pada saat sampai 5 hari setelah pengumuman merger dan akuisisi. * signifikan pada $\alpha=5 \%$. IOS menunjukkan set kesempatan investasi. CF menunjukkan aliran kas.

\begin{tabular}{|c|c|c|}
\hline CF & Tinggi & Rendah \\
\hline \multirow[t]{3}{*}{ Tinggi } & AAR $=-0,01658(-0,00911)$ & AAR $=-0,03535(-8,014832)^{*}$ \\
\hline & $\mathrm{CAAR}_{2}=-0,13646(-0,17223)$ & $\mathrm{CAAR}_{2}=-0,00928(-0,55467)$ \\
\hline & $\mathrm{CAAR}_{5}=-0,15059(-0,35225)$ & $\mathrm{CAAR}_{5}=-0,0898(-3,29299)^{*}$ \\
\hline \multirow[t]{3}{*}{ Rendah } & $\operatorname{AAR}=0,00984(0,31820)$ & AAR $=-0,00002(-0,00135)$ \\
\hline & $\mathrm{CAAR}_{2}=0,00938(0,32214)$ & $\mathrm{CAAR}_{2}=-0,02282(-0,72502)$ \\
\hline & $\mathrm{CAAR}_{5}=0,05007(0,72816)$ & $\mathrm{CAAR}_{5}=0,02124(0,68069)$ \\
\hline
\end{tabular}




\section{Tabel 5}

\section{Hubungan Aliran Kas Bebas dengan Set Kesempatan Investasi Merger dan Akuisisi \\ SKT Rendah}

AAR (Average Abnormal Return) menunjukkan besarnya reaksi pasar pada periode $t$ atau saat pengumuman merger dan akuisisi. CAAR 2 (Cumulative Average Abnormal Return) menunjukkan reaksi pasar pada periode 2 hari sebelum sampai 2 hari sesudah pengumuman merger dan akuisisi. CAAR 5 (Cumulative Average Abnormal Return) menunjukkan reaksi pasar pada saat sampai 5 hari setelah pengumuman merger dan akuisisi. * signifikan pada $\alpha=5 \%$. IOS menunjukkan set kesempatan investasi. CF menunjukkan aliran kas.

\begin{tabular}{|c|c|c|}
\hline $\mathrm{CF}_{\mathrm{CF}} \mathrm{IOS}$ & Tinggi & Rendah \\
\hline \multirow[t]{2}{*}{ Tinggi } & $\begin{array}{l}\mathrm{AAR}=-0,01495(-1,03257) \\
\mathrm{CAAR}_{2}=0,02527(1,27623)\end{array}$ & $\begin{array}{c}\text { AAR }=-0,03593(-7,17989)^{*} \\
\text { CAAR }_{2}=0,00210(0,07177)\end{array}$ \\
\hline & $\mathrm{CAAR}_{5}=-0,01130(-0,48910)$ & $\mathrm{CAAR}_{5}=-0,05227(-2,41960) *$ \\
\hline \multirow[t]{3}{*}{ Rendah } & $\mathrm{AAR}=0,02555(0,72894)$ & $A A R=-0,09392 \quad(0,03889)$ \\
\hline & $\mathrm{CAAR}_{2}=0,06232(2,09004)$ & $\mathrm{CAAR}_{2}=-0,11307(-1,35420)$ \\
\hline & $\mathrm{CAAR}_{5}=0,05251(1,15760)$ & $\mathrm{CAAR}_{5}=-0,01519(0,51094)$ \\
\hline
\end{tabular}

Tabel 6

Hasil Uji Regresi

$\mathrm{ROE}=\alpha_{i}+\beta_{1}$ Own $+\beta_{2}$ Invest $+\beta_{3}$ (Own x Invest) $+\mu_{i}$

Variabel dependennya ROE = Return On Equity. Variabel independennya adalah Own $=1$ untuk struktur kepemilikan terkonsentrasi tinggi, Own $=0$ untuk struktur

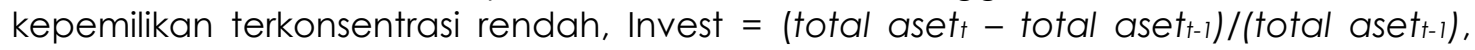
Investown = investasi pada struktur kepemilikan terkonsentrasi. ${ }^{*}=$ signifikan pada $\alpha=$ $5 \%$.

\begin{tabular}{|c|c|c|c|}
\hline Model & $\begin{array}{c}\text { Unstandardized } \\
\text { Coefficients } \\
(\beta)\end{array}$ & $\mathbf{T}$ & Signif \\
\hline Constant & 72,41800 & 3,65200 & 0,00000 \\
\hline Own & $-33,26400$ & $-1,53500$ & 0,01270 \\
\hline Invest & 23,52200 & 2,58600 & 0,01100 \\
\hline Invesown & $-23,5900$ & $-2,59100$ & 0,01100 \\
\hline $\mathrm{R}^{2}$ & 0,01480 & & \\
\hline $\mathrm{F}$ & 3,48400 & & \\
\hline
\end{tabular}


* Mutamimah adalah staff pengajar di Fakultas Ekonomi Universitas Sultan Agung (UNISSULA) Semarang. Kritik dan dan saran dapat langsung menghubungi penulis dengan alamat email tatikmut@yahoo.com 